\title{
International Underground Commercial Space Development and
}

\section{Utilization Experience}

\author{
Li Wei $^{1}$, Chen zhilong ${ }^{1}$, Yang Xiaobin ${ }^{1}$, Peng Yao ${ }^{2}$ \\ ${ }^{1}$ Research Center of Underground Space, PLA Univ. of Sci. \& Tech. Nanjing 210007, China \\ ${ }^{2}$ Naval Engineering Design Research Bureau, Beijing 100070, China
}

Keywords: Underground space, Commercial facilities, Cases.

\begin{abstract}
In the process of the underground space development, the first is the development of underground municipal facilities, marks the beginning of modern urban underground space development and utilization. In order to adapt to urban development and then appears the underground traffic, expanded the contents of the underground space. Lately developed underground commercial is a comprehensive collection of traffic, disaster prevention and so on. The paper focuses on both success and insufficiency international underground commercial space development cases and finds some conclusions.
\end{abstract}

\section{Introduction}

After the first industrial revolution, the quality of urbanization enjoys a rapid improvement with the rapid development of productivity. The backward city facilities cannot satisfy the needs of the city, leading to increase in construction of urban water supply, drainage and other facilities, and thus began the modern urban underground space utilization. Underground facilities hold the balance of the human activities and the nature. The rapid development of underground traffic in the 1930s, promotes the national economy as a whole. One of the most obvious outcomes is underground business, which is an expansion of underground sidewalks or pedestrian crossing tunnel in the early time.

Perth has a small network of underground shopping malls running from the St Georges Terrace entrance to Trinity Arcade to Murrey Street Mall.

The small town of Coober Pedy in northern South Australia has numerous underground residences and other facilities. The area was and is extensively mined for opal, and the settlers lived underground to escape the scorching daytime heat, often exceeding $40^{\circ} \mathrm{C}\left(104^{\circ} \mathrm{F}\right)$.

Underground commercial cases

Sydney has a series of underground shopping malls around the underground station Town Hall. The tunnels run south to the George Street cinema district, west under the town hall, and north to Pitt Street Mall through the Queen Victoria Building. The northern branch links Queen Victoria Building with Galleries Victoria, Sydney Central Plaza (which in turn links underground to Westfield CentrePoint and internally above ground to Centrepoint, Imperial Arcade, Skygarden, Glasshouse, and the MLC Centre). The linked centres run for over $3 \mathrm{~km}$ (2 mi). In 2005, Westfield corporation submitted a development application to link Sydney Central Plaza underground with 3 other properties on Pitt Street Mall and extend the tunnel network by a further $500 \mathrm{~m}(1,640 \mathrm{ft})$ or more.

Santiago has some elements of an underground city in its "Metro" subway system. While all stations have a small mezzanine level above the tracks for ticket purchase, some key stations have extensive areas of shops and kiosks in addition. Some stations even have an additional mall-like level between the street and the mezzanine levels. 
Beijing built an extensive tunnel network called the Underground City during the Sino-Soviet conflict, supposedly covering $85 \mathrm{~km}^{2}$, falling into disuse in the 1970s. It has been recently[when?] opened to the public and tourists. There are rumors it was used by the army during the Tiananmen incident. As of 1 July 2009, all "official" remaining entrances appear to be closed.

Harbin has a number of large, multi-level underground shopping areas, originally built for air defence. The largest is at the roundabout intersection of Xida Zhi street and Hongjun street where three levels of markets following streets from four directions meet under the giant snowflake atrium.

Hong Kong: Many MTR stations in Hong Kong form extended underground networks connecting to buildings and at the basement of some major shopping malls in the area above.The stations themselves house a number of retail shops. Notable examples are the Central - Hong Kong stations and the Tsim Sha Tsui-East Tsim Sha Tsui stations. Only rarely are there not any shops.

Qingdao has two small underground shopping areas, one at the head of the Zhanqiao (pier) and one west of the Qingdao guest house.

Shanghai has a few underground networks, most notably at the People's Square metro station, wherein the line 2 station has a second mezzanine full of shops and line 1 is connected to a large underground shopping gallery at its south end. Shanghai Science Museum stop on line 2 has a large underground shopping area, known for its imitation goods. Huangpi Road South and Xujiahui stations are directly connected to shopping centers, and the Lujiazui station is connected to the Bank of China tower.

Berlin: Several buildings on the east side of Friedrichstraße, from Quartier 205 (Friedrichstraße 70) northwards up to Galerie Lafayette are connected to each other. Businesses are on both sides of the underground street so that it appears to be inside a building all the time, even when it crosses Taubenstraße underground.

Frankfurt am Main: Underground shopping malls, called 'B-Ebene' in Frankfurt, of considerable size are found at Hauptbahnhof (central station) and Hauptwache.

Hamburg: The Jungfernstieg and Rathaus subway stations and several entrances are connected by pedestrian tunnels. Some of them contain shops. There is a direct access to the Europapassage shopping mall.

Stuttgart: There is a large underground shopping mall (Klettpassage) connecting the Hauptbahnhof (central station) with the main shopping street, the Königstraße.

Table 1: Some Underground Commercial Cases

\begin{tabular}{|c|c|c|c|c|}
\hline Country & Name & Scale $\left(\mathrm{m}^{2}\right)$ & Experience & Remarks \\
\hline \multirow[b]{2}{*}{ Japan } & Tokyo yaesu & 74,000 & $\begin{array}{c}\text { 3D redevelopment near two stations, } \\
\text { connected with the basement of surrounding } \\
\text { buildings }\end{array}$ & $\begin{array}{l}8 \text { metro lines, } 3 \text { floors } \\
\text { underground, } 150 \mathrm{~m} \text { long[1] }\end{array}$ \\
\hline & Kawasaki, jie leah & 57,000 & $\begin{array}{l}\text { Directly lead the people into the } \\
\text { underground street, solves the mixed traffic } \\
\text { in the square }\end{array}$ & $\begin{array}{l}\text { First annual loss of } \$ 80 \\
\text { million, profit after } 11 \\
\text { years, } 20 \text { years recover all } \\
\text { the investment[2] }\end{array}$ \\
\hline France & DE Paris & $1,000,000$ & $\begin{array}{l}\text { Double city with ground and underground } \\
\text { traffic completely separated, effective } \\
\text { protection of historical style and features, } \\
\text { life quality improvement }\end{array}$ & Government supported[3] \\
\hline \multirow[b]{2}{*}{ Canada } & Montreal & $5,800,000$ & $\begin{array}{l}\text { Underground traffic network all over the } \\
\text { city, the ground and underground } \\
\text { commercial each half }\end{array}$ & $\begin{array}{l}36 \mathrm{~km}^{2}, 1 / 10 \text { the size of the } \\
\text { city,35\% of the center area } \\
\text { commercial }\end{array}$ \\
\hline & $\begin{array}{l}\text { Toronto Eaton } \\
\text { Centre }\end{array}$ & 560,000 & $\begin{array}{l}\text { Underground pedestrian system connected } \\
\text { to the underground shopping center, subway } \\
\text { station, improved lighting and flow } \\
\text { distribution }\end{array}$ & Government supported \\
\hline US & $\begin{array}{l}\text { Georgetown } \\
\text { university in } \\
\text { Washington, tesla }\end{array}$ & 13,200 & $\begin{array}{c}\text { Enlarge the space capacity, land saving, } \\
\text { energy efficiency }\end{array}$ & $\begin{array}{l}\text { Less than the ground gym } \\
\text { cost, operating cost to } 1 / 3 \\
\text { of the ground[4] }\end{array}$ \\
\hline Sweden & $\begin{array}{l}\text { Siegel square in } \\
\text { Stockholm }\end{array}$ & 800,000 & $\begin{array}{l}\text { Improve traffic, creating high quality city } \\
\text { atmosphere }\end{array}$ & Government supported \\
\hline
\end{tabular}




\begin{tabular}{|c|c|c|c|c|}
\hline \multirow{5}{*}{ China } & $\begin{array}{l}\text { Beijing Exhibition } \\
\text { Center south } \\
\text { square }\end{array}$ & 40,000 & $\begin{array}{c}\text { A total area of } 18000 \mathrm{~m}^{2} \text {, more than } 90 \% \\
\text { foreign trade clothing, mainly to the } \\
\text { wholesale }\end{array}$ & Superior location[5] \\
\hline & $\begin{array}{l}\text { Shanghai Jingan } \\
\text { Temple Square }\end{array}$ & 11,000 & $\begin{array}{c}\text { Unimpeded walking system, impressed } \\
\text { space,ecological environment,orderly } \\
\text { movement system }\end{array}$ & $\begin{array}{l}\text { Plenty of underground } \\
\text { parking ensures the } \\
\text { prosperity }\end{array}$ \\
\hline & $\begin{array}{l}\text { Dalian Shengli } \\
\text { Square }\end{array}$ & 120,000 & $\begin{array}{l}\text { Ease traffic congestion, traffic extending in } \\
\text { all direction }\end{array}$ & $\begin{array}{l}2 \text { buildings allowed on } \\
\text { square as compensation }\end{array}$ \\
\hline & $\begin{array}{l}\text { Nanjing Palace } \\
\text { Square }\end{array}$ & 42,000 & For commercial and parking lots & $\begin{array}{l}\text { Truck available, civil } \\
\text { defense engineering }\end{array}$ \\
\hline & $\begin{array}{l}\text { Harbin Gogol } \\
\text { Street }\end{array}$ & 20,000 & $\begin{array}{l}\text { Develop brand business, improve the } \\
\text { consumption level and environment, serve } \\
\text { for citizens and tourists }\end{array}$ & $\begin{array}{c}\text { The first underground } \\
\text { national civil defence } \\
\text { business street }\end{array}$ \\
\hline
\end{tabular}

\section{Analysis of the cases}

Urban underground commercial utilization is no longer a single use, combined with the trend of comprehensive development and utilization, realizing city function integration.

i) Location advantage: all kinds of location within the city, such as urban commercial centre, underground rail transit hub and urban transport hub, have a strong attraction to the underground business, so underground commercial potential value is high[6]. Space location level is directly related to underground commercial development demand and its economic benefits. The closer the distance between the space location, the greater the demand of underground commercial development, and the higher the economic benefits. [7]

ii) Convenient transportation: international underground commercial illustration construction experience shows that underground commercial exert its function only when traffic planning works. And simple commercial space often lack competitiveness compared with the ground commercial facilities. Underground commercial space can be connected to the subway station space such as the hall, in the realization of traffic evacuation and fully tap its commercial potential, and further improve the efficiency of urban land.

iii) Underground interaction: underground commercial styles links closely to its business area, or attaches to the mature of the ground and the surrounding business atmosphere[8]. Underground commercial development promotes the regional comprehensive commercial forms and function division above and underground, making the business model more mature and comprehensive in the whole area, realizing the interaction between ground and underground commercial.

\section{Conclusion}

Through the research and construction of international commercial underground space development, both success and insufficiency can be found. The following conclusions and suggestions can be reached.

i) Developing underground space planning. Underground space development and utilization is important for the sustainable development of urban areas, but it must have a complete planning system to avoid the huge waste of resources and money.

ii) Ground and underground space planning interaction. The underground space planning is not simply about underground space itself, but plays an important role in the planning system. The systemic is not through simply connected underpass, but a reorganization and redistribution to the traffic line orderly arrangement, and also a result of technology, economy, behaviour balanced and unified planning.

iii) Related policy of underground space development and utilization. Underground space development and utilization is the inevitable trend and result of city development, but actively 
guidance from the government is also very important. The development and utilization of underground space is a costly construction projects, first of all, relevant policies and regulations to attract and safeguard the interests of investors should be formulated. At the same time, positive policies to encourage underground space construction could be added.

\section{References}

[1] Gideon S. Golang, Toshio Ojima.Urban underground space design. Beijing: China Building Industry Press, 2005.

[2] Tong Linxu. Underground construction drawings 100 cases. Beijing: China Building Industry Press, 2007.

[3] CHEN Zhilong. Urban Underground Space Master Plan. Nanjing: Southeast University Press, 2011.

[4] R.K.Goel, Bhawani Singh, Jian Zhao. Underground infrastructures, planning, design, and construction. USA: Butterworth-Heinemann, 2012.

[5] Wu Xin. Underground urban public space design method. Xiamen: Xiamen University, 2006.

[6] Heungsoo Jeon, Yonggu Jang. Development of underground structure fields control system based on Ubi-GIS technique. M. Zhou \& E. Zhu. Information and Communication Technology for Education. Britain: WIT Press, 2014.

[7] Jiro Kato, Masao Ando. Force of interior space design manual. Beijing: China Construction Press, 2003.

[8] Geng Yongchang, Zhao Xiaohong. Construction of urban underground space. Harbin: Harbin Institute of Technology Press, 2001. 